\title{
Recent status of gelatin-resorcin-formalin glue for acute type A aortic dissection
}

\author{
Kiyotaka Imoto, MD, PhD
}

Received: 9 April 2010 / Accepted: 7 May 2010

(C) The Japanese Association for Thoracic Surgery 2011

Gelatin-resorcin-formalin (GRF) glue was developed by Braunwald and Tatooles in 1964. Initially, it was mainly used as a hemostatic agent by gastrointestinal surgeons and urologists. ${ }^{1}$ In 1977, Bachet et al. ${ }^{2}$ used GRF glue as an adhesive and hemostatic material for aortic surgery and reported that it was very useful. The use of GRF glue dramatically improved the outcomes of surgery for Stanford type A acute aortic dissection, previously associated with high mortality due to frequent intraoperative bleeding from the fragile aortic wall tissue. Shimono et al. ${ }^{3,4}$ reported that the introduction of GRF glue markedly improved surgical outcomes, decreasing the in-hospital mortality to $6.7 \%$. In surgery for acute type A aortic dissection, GRF glue decreases the risk of bleeding by holding together and reinforcing the dissected aortic wall during the acute phase and preventing bleeding from suture sites. The study of Isoda et al. ${ }^{6}$ focused on the former effect.

The formalin component of GRF glue promotes polymerization of gelatin-resorcin, resulting in a threedimensional network. This network underlies the adhesive strength of GRF glue. ${ }^{5}$ Clinically, however, there is currently no standardized component ratio for GRF glue, and different formulations are used. Because formalin is toxic to tissue, the minimum concentration required for effective adhesion should be used. Isoda

This editorial refers to the article by Isoda et al. on pp. 326-328 of this issue of General Thoracic and Cardiovascular Surgery.

K. Imoto $(\bowtie)$

Department of Cardiovascular Surgery, Yokohama City

University, Medical Center, 4-57 Urafune-cho, Minami-ku,

Yokohama 232-0024, Japan

Tel. +81-45-261-5656; Fax +81-45-261-9162

e-mail: imoto@urahp.yokohama-cu.ac.jp et al. showed that an activator/adhesive combination ratio of about 0.1 is minimally required to produce the highest adhesive effect. ${ }^{6}$ This finding might be useful for decreasing the amount of formalin. To assess adhesive strength, Kunihara et al. evaluated the degree of GRF polymerization for an activator/adhesive ratio ranging from 0 to 0.1 . They similarly found that a ratio of 0.1 resulted in the greatest polymerization and highest adhesive strength. ${ }^{5}$

However, even when used at the lowest combination ratio required for maximum adhesive strength, formalin can still potentially damage tissue. Such damage is not appreciable during the early postoperative period. Suzuki et al. reported the development of false aneurysms at the aortic root 30 months after initial surgery, on average. ${ }^{7}$

Fukunaga et al. reported on clinically induced tissue injury related to the use of formalin in 1990. In all, 7 $(6.4 \%)$ of 109 patients who tolerated surgery with the use of GRF glue required reoperation after 22.6 months. on average. for redissection of the aortic root attributed to the use of GRF glue at initial surgery. ${ }^{8}$ Bingley et al. performed reoperation for redissection of the aortic root in $12 \%$ of patients 33 months after initial surgery, on average. ${ }^{9}$ Redissection of the aortic root was reported to occur at an incidence of $7 \%$ by Kazui et al., ${ }^{10} 64 \%$ by Von Opell et al., ${ }^{11}$ and $50 \%$ of 50 patients by Nakajima et al. ${ }^{12}$ Nakajima et al. used GRF glue prepared by adding only 2 to 3 drops of formalin to $1 \mathrm{ml}$ of gelatinresorcin, as recommended by Bachet et al., ${ }^{2}$ in the last 16 patients of a series but reported that redissection occurred at a high rate $(37 \%)$ during the late stage. ${ }^{12}$ Suzuki et al. reported that false aneurysms associated with dehiscence of the proximal suture line developed in 31 of 193 survivors among 221 patients with acute type 
A dissection accompanied by false aneurysms who underwent surgery with the use of GRF glue. ${ }^{7}$ Formalin was added in 0.04-ml drops with the use of a small syringe. Three to five drops of formalin $(0.12-0.20 \mathrm{ml})$ were added to $3-5 \mathrm{ml}$ of gelatin-resorcin (activator/ adhesive ratio $=0.04$ ). Microscopic examination of the tissue to which GRF glue was applied revealed medial degeneration and disappearance of the nuclei of medial smooth muscle cells. These findings suggested that GRF glue can cause degeneration and necrosis of the media even if the activator/adhesive ratio is within appropriate limits.

Some reports have claimed that midterm and longterm complications associated with GRF glue can be prevented by proper use. Bachet et al. ${ }^{1,2}$ reported that no aortic lesions were caused by GRF glue during 20 years of experience, and Shimono et al. ${ }^{3,4,13,14}$ found no evidence of cytotoxicity or tissue necrosis, although reoperation was performed for redissection caused by GRF glue in 1 of 138 patients who underwent surgery. Shimono et al. reinforced the aortic stump with Teflon felt after applying GRF glue to the dissected aortic wall, whereas Fukunaga et al., ${ }^{8}$ Von Opell et al., ${ }^{11}$ Nakajima et al., ${ }^{12}$ and Suzuki et al. ${ }^{7}$ did not. The use of Teflon felt reinforcement might thus lower the incidence of redissection and false aneurysms during the late stage.

Even if no clinical evidence of tissue damage is apparent, GRF glue may still injure tissue. This is another reason the use of GRF glue should be discontinued as soon as a new surgical procedure is shown to have early outcomes equivalent to those of surgery with the use of GRF glue.

\section{References}

1. Bachet J, Goudot B, Teodori G, Brodaty D, Doubois C, Delentdecker $\mathrm{P}$, et al. Surgery of type A acute aortic dissection with gelatine-resorcine-formol biological glue: a twelve-year experience. J Cardiovasc Surg 1990;31(suppl):263-73.
2. Bachet J, Goudot B, Dreyfus G, Banfi C, Ayle NAL, Aota M, et al. The proper use of glue: a 20-year experience with the GRF glue in acute aortic dissection. J Card Surg 1997; 12(suppl):243-55.

3. Shimono M, Hata M, Sezai A, Niino T, Yagi S, Negishi N. Validity of a limited ascending and hemiarch replacement for acute type A aortic dissection. Ann Thorac Surg 2006;82: 1665-9.

4. Shimono M. Surgery for acute aortic dissection using gelatinresorcin-formalin glue: perspective from 10 years of follow-up at a single center. J Artif Organs 2008;11:19-23.

5. Kunihara T, Iizuka K, Sasaki S, Shiiya N, Sata F, Matsui Y. Optimal proportions of gelatin-resorcin-formalin components in aortic surgery. Eur J Cardiothorac Surg 2009;36:962-6.

6. Isoda S, Kimura T, Mashiko Y, Nakamura S, Maehura T. In vitro study of the optimum volume ratio of activator to adhesive in gelatin-resorcin-formalin glue. Gen Thorac Cardiovasc Surg (in press).

7. Suzuki S, Imoto K, Uchida K, Takanashi Y. Aortic root necrosis after surgical treatment using gelatin-resorcinolformaldehyde (GRF) glue in patients with acute type A aortic dissection. Ann Thorac Cardiovasc Surg 2006;12:333-40.

8. Fukunaga S, Karck M, Harringer W, Cremer J, Rhein C, Haverich A. The use of gelatin-resorcin-formalin glue in acute aortic dissection type A. Eur J Cardiothorac Surg 1999;15: 564-9.

9. Bingley JA, Gardner MA, Stafford EG, Mau TK, Pohlner PG, Tam RKW, et al. Ann Thorac Surg 2000;69:1764-8.

10. Kazui T, Washiyama N, Bashar AHM, Terada H, Suzuki K, Yamashita K, et al. Role of biologic glue repair of proximal aortic dissection in the development of early and midterm redissection of the aortic root. Ann Thorac Surg 2003;75: 1063-4.

11. Von Oppell UO, Karani Z, Brooks A, Brink J. Dissected aortic sinuses repaired with gelatin-resorcin-formaldehyde (GRF) glue are not stable on follow up. J Heart Valve Dis 2002;11:249-57.

12. Nakajima T, Kawazoe K, Izumoto H, Kamada T, Kataoka $\mathrm{T}$, Yoshioka $\mathrm{K}$, et al. Influence of gelatin-resorcin-formalin glue on mid-term redissection after aortic repair. Surg Today 2005;35:112-6.

13. Shimono M, Hata M, Sezai A, Niino T, Yagi S, Negishi N. Late results of gelatin-resorcin-formalin glue aided repair in acute type A aortic dissection. Artif Organs 2006;30: 962-5.

14. Hata M, Shimono M, Sezai A, Iida M, Negishi N, Sezai Y. Type A acute aortic dissection: immediate and mid-term results of emergency aortic replacement with the aid of gelatinresorcin-formalin glue. Ann Thorac Surg 2004;78:853-7. 